\title{
LABORATORY INVESTIGATION ON CONTROLLING CAST IRON GALVANIC CORROSION IN COLUMBIA RIVER WATER
}

\author{
A. P. Larrick
}

APRIL 1968

\section{AEC RESEARCH \& DEVELOPMENT REPORT}

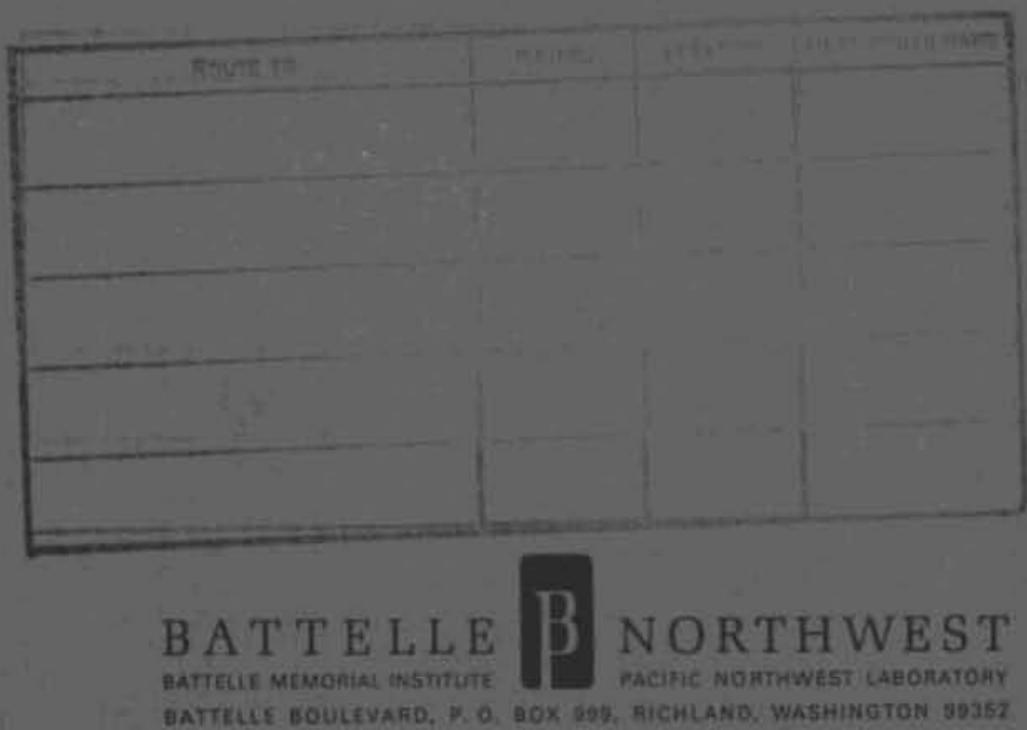




\section{LEGAL NOTICE}

This report was prepared as an account of Government sponsored work. Neither the United Stotes, nor the Commission, nor any person acting on behalf of the Commission:

A. Makes ony warranty or represantation, expressed or implied, with respest to the occuracy, com. plateness, or useluiness of the information contained in this reporl, or that the use of any information. opparatus, method, or process disctesed in this report miay not infringe privately owned rightss or

B. Assumes any liobilities with respect to the use of, or for damages resulting from the use of ony information, apparatus, method, or process disclosed in this repor1.

As used in the obove, "person acting on beholf of the Commission" includes any employed or contractor of the Commission, or employee of such contractor, to the extent that such employee or con. tractor of the Cammission, or employee of such contractor propares, disseminates, or provides access to, any information pursuant to his employment or contract with the Commission, or his employment with such contractor.

\section{PACIFIC NORTHWEST LABORATORY \\ MCHLAND, WASHINGTON \\ operated by \\ BATTELLE MEMORIAL INSTITUTE}

for the

UNITED STATES ATOMIC ENERGY COMMISSION UNDER CONTRACT AT(45-1)-1830 


\author{
By \\ Alvin P. Larrick \\ Surface and Coolant Chemistry Section \\ Chemistry and Chemical Engineering Department
}

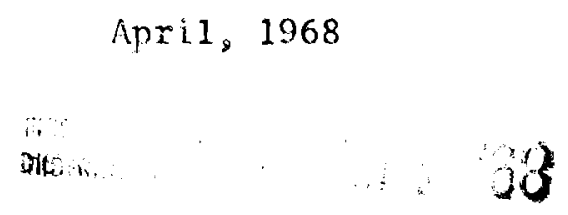

PACIFIC NORTHWEST LABORATORY

RICHLAND, WASHINGTON 
LABORATORY INVESTIGATION ON CONTROLLING CAST IRON

GALVANIC CORROSION IN COLIMBIA RIVER WATER

Alvin $\mathrm{P}$ 。Larrick

\section{INTRODUCTION}

A recent inspection of the $K-$ Area diese1-engine powered emergency cooling water pumps indicated that severe corrosion has been occurring to the cast iron pump bow1s. A residual spongy graphite layer up to $1 / 2$ inch thick was found at some areas indicating that at least 1/4-inch of iron had been corroded away.

These pumps are not operated except for a short test period about once every thirty days. During the test period the pumps are started and fresh, filtered, Columbia River water (adjusted to $\mathrm{pH} 6.6$ ) is pumped through the pumps and adjacent piping. During the remaining time stagnant water is in contact with the pumps.

An evaluation of the conditions existing in the pumps indicated that the corrosion resulted from a galvanic coupling between the cast iron pump housing and the brass impeller。

The normal solution to this corrosion problem would be to replace the brass impeliers with cast iron or steel impellers to remove the source of the galvanic currents. However, this would be fairly expensive, and since the water in the pumps is only infrequently replaced $s$ it was decided to investigate the possibility of adding inhibitors or changing the water chemistry in some way to control the galvanic corrosion currents. Laboratory tests conducted to verify that the corrosion was due to galvanic currents between the brass and cast Iron and other tests to determine methods of reducing the corrosion are reported in this document.

\section{SUMMARY AND CONCLUSIONS}

Laboratory tests indicate that the probable cause of corrosion on $K$ Area diesel-engine powered emergency coolant pump bowls and vanes is a galvanic current flowing between the brass impeller and the cast 
iron bow1. Increasing the $\mathrm{pH}$ from 6.6 to 11.0 and adding catalyzed sodium sulfite to either $\mathrm{pH} 6.6$ or $\mathrm{pH} 11.0$ water substantially decreased the currents flowing between brass-cast iron galvanic couples. Pitting occurred on the cast iron in the $\mathrm{pH} 11.0$ tests; therefore, sulfite addition to pH 6.6 water is the preferred method of reducing the galvanic corrosion. A readily available source of sodium sulfite deoxygenated water makes this method of inhibition practicable. The pumps are currently exposed to $\mathrm{pH} 6.6$ water.

A secondary galvanic couple is set up between the cast iron and graphite, and the corrosion currents originating from this couple were not always reduced by sulfite additions. It may be necessary to remove the graphite layers from the pumps to obtain inhibition of cast iron if sulfite additions are employed.

Use of a commercial zinc phosphate-chromate inhibitor as an alternate method of reducing the corrosion was investigated, and was shown to substantially reduce the corrosion currents when the cast iron was coupled to either brass or graphite. However, this method of inhibition may not be practicable because of potential activation of the solution if it enters a nuclear reactor and subsequent pollution problems.

Investigations into the mechanisms of the inhibition showed that in the presence of sulfite the brass cathodic half-cell was markedly polarized. In the presence of the zinc-phosphate-chromate solution both the anodic (iron dissolution) and cathodic half-cell currents were substantially reduced. Potentiostatic tests indicated the brass halfcell polarization was related to oxygen reduction at the brass (cathodic) surface.

\section{EXPERIMENTAL}

Potential and current measurements on ASTM A145-5B brass, gray cast iron, and pure graphite were conducted in the apparatus shown in Figure 1. Open circuit and coupled potentials were measured versus a saturated calomel electrode. The open circuit potential is the potential assumed by the sample when electrically insulated from all 
other materials except the liquid. The coupled potential is the potential of two different alloys short circuited across a one-ohm resistor. Currents were calculated from measurements of the potential drop across the resistor and application of $0 \mathrm{hm}^{\prime} \mathrm{s}$ Law. A one-ohm resistor is a very small resistance in the total cell resistance and the resultant current is close to the short-circuit current. Spacing between the various electrodes was 1 to $11 / 2$ inches.

The type of cast iron used in the K-Area pumps could not be determined but the A48 No. 35 gray cast iron coupons used in the laboratory tests are typical of material used in many pump applications.Coupon size was $1 \times 1 \times 0.1-i$ inch.

The area where the lead-out wire was soldered to the sample was covered with Krylon paint; the total remaining exposed area was $2.19 \mathrm{in}^{2}$. The ASTM B-145 5B brass alloy $(75.68 \mathrm{Cu}, 2.92 \mathrm{Sn}, 6.12 \mathrm{~Pb}, 0.12 \mathrm{Sb}$, $\left.0.21 \mathrm{Fe}_{3}, 14.75 \mathrm{Zn}, 0.20 \mathrm{Ni}\right)$ coupon material was similar but not exactly the same in composition as the $K$ Area $B 143$ brass pump impellers ( $88 \mathrm{Cu}$, $6-10 \mathrm{Sn}_{2} 0-1,5 \mathrm{~Pb}_{2}, 2-4.5 \mathrm{Zn}$ ). Corrosion behavior is expected to be similar. Coupon size was $41 / 2 \times 1 / 2 \times 1 / 8$-inch and surface area after covering the leadoin wire connections was $5.02 \mathrm{in}^{2}$.

The pure graphite was a $5 / 8 \times 1 / 2 \times 21 / 2$-inch bar with a $7 / 16$-inch diameter $x$ l-inch long cylinder machined at one end. Total area was 7.3 in $^{2}$.

Cathodic polarization curves were obtained using similar size samples except that the graphite surface area was reduced to $2.8 \mathrm{in}^{2}$. The experiments to obtain the cathodic polarization curves were conducted in a $500 \mathrm{ml}$ glass container fitted to hold the corrosion samples, reference electrode, platinum counter electrodes and a piece of tubing to bubble gas through the solution. A magnetic stirrer was used during some of the runs. The polarization curves were obtained by the potentiostatic method. A Wenking potentiostat was used to hold the potential at a constant value of overpotential from the sample's rest potential and to record the current required to polarize the sample. Once the current had become constant, the overpotential was increased an incremental amount and the current recorded for the new value of overpotential. 
The water used was City of Richland, Washington, filtered water. This water is filtered Columbia River water similar to that used in the $K$ Area diesel-powered emergency coolant pumps. The pH was adjusted to either 6.6 with sulfuric acid or 11.0 with sodium hydroxide. The $\mathrm{pH}$ was adjusted before sulfite additions for the tests containing sodium sulfite; the sulfite raised the pH slightly.

\section{RESULTS}

Current versus Time Studies

Samples of cast iron and brass were connected across a 1-ohm resistor as shown in Figure 1 in solutions of a) $\mathrm{pH} 6.6$ water; b) $\mathrm{pH} 6.6$ water containing $150 \mathrm{ppm}$ sodium sulfite, $0.06 \mathrm{ppm}$ cobaltous nitrate; c) pH 11.0 water; and d) $\mathrm{pH} 11.0$ water containing $150 \mathrm{ppm}$ sodium sulfite, $0.06 \mathrm{ppm}$ cobaltous nitrate. The first solution represented conditions similar to those in the $K$ Area pumps and the other three solutions represented possible water chemistries to inhibit the corrosion.

The current flowing between the samples, an indication of the galvanic corrosion occurring on the cast iron anodic half of the couple, is shown as a function of time in Figure 2. The initial current of $0.59 \mathrm{~mA}$ in the $\mathrm{pH} 6.6$ water was reduced to $0.46 \mathrm{~mA}$ by increasing the $\mathrm{pH}$ to 11.0 , to $0.28 \mathrm{~mA}$ by adding sulfite to $\mathrm{pH} 6.6$ water, and to $0.13 \mathrm{~mA}$ by increasing the $\mathrm{pH}$ and adding sulfite. The reduced current flow obtained by only increasing the $\mathrm{pH}$ did not persist, however, and the currents over the one-week test period ranged from 0.45-0.68 mA for couples exposed to solutions at pH 6.6 and pH 11.0 without sulfite additions 。

The corrosion currents between the samples in the sulfite treated solutions slowly increased with time until after one day of testing the currents flowing on these samples were nearly equal to the currents flowing between the samples in the non-sulfite treated solutions. An additional $150 \mathrm{ppm}$ sulfite added at this time reduced the corrosion currents to almost zero, indicating that oxygen from the air had slowly dissolved in the test solutions during the first day of testing and increased the corrosion. (Sodium sulfite with 
cobaltous ion acting as a catalyst removes dissolved oxygen from water according to the following equation: $2 \mathrm{Na}_{2} \mathrm{SO}_{3}+\mathrm{O}_{2} \rightarrow 2 \mathrm{Na}_{2} \mathrm{SO}_{4}$ ) After an additional day of exposure atmosphereric oxygen gradually used up the remaining sulfite (verified by sulfite analysis on 4th day of test), and corrosion currents increased.

The above test was repeated with new samples and fresh solutions; similar results were obtained.

The currents remained near zero and did not increase with time in a later test in which nitrogen gas was bubbled through sulfitetreated pH 6.6 water. This test showed that galvanic corrosion can be permanently reduced if the oxygen is kept completely away from the corroding brass-cast iron couple.

Corrosion penetrations from the weight loss data on the coupons, as shown in Table 1 , showed trends similar to the current data.

TABLE 1

COUPON CORROSION LOSSES DURING CURRENT-TIME TESTS, Mi 1S

\begin{tabular}{|c|c|c|c|c|}
\hline \multirow[t]{2}{*}{ Solution } & \multicolumn{2}{|c|}{ Test No. 1} & \multicolumn{2}{|c|}{ Test No. 2} \\
\hline & Cast Iron & Brass & Cast Iron & Brass \\
\hline pH 6.6 filtered water & 0.46 & 0.023 & 0.67 & .056 \\
\hline $\begin{array}{l}\text { pH } 6.6 \text { filtered water } \\
\text { plus sodium sulfite }\end{array}$ & 0.33 & 0.005 & 0.27 & .033 \\
\hline $\mathrm{pH} 11.0$ filtered water & 0.48 & 0.020 & 0.44 & .007 \\
\hline pH 11.0 filtered water & 0.27 & 0.026 & 0.22 & .008 \\
\hline
\end{tabular}

The cast iron corrosion was reduced slightly by increasing the $\mathrm{pH}$ from 6.6 to 11.0 , was reduced further by adding sulfite to $\mathrm{pH} 6.6$ water, and was reduced most by adding sulfite and adjusting the $\mathrm{pH}$ to 11.0 . Brass corrosion was small because it was the cathode (non-corroding element) of the couple. (Some corrosion occurs on the brass due to presence of local anodic sites on the brass surface.)

The visual observations on the samples and solutions during the current-time tests also gave a good indication of the corrosion occurring. 
The $\mathrm{pH} 6.6$ water turned orange within a few hours of testing indicating substantial ixon corrosion products were going into solution. The sulfitetreated pH 6.6 water did not turn orange until after the sulfite was depleted, about one day, Flocculent, greenish-black corrosion products appeared on the samples in both $\mathrm{pH} 11.0$ and $\mathrm{pH} 11.0$ plus sulfite solutions within a few hours. These flocculent formations covered approximately $10 \%$ of the sample area indicating that a form of localized corrosion was occurring. Material kept sloughing from these areas until at the end of the week the entire bottom of the container was covered with the material. Examination of the samples after completion of the experiment revealed pits up to $25 \mathrm{mils}$ deep at the areas where the flocculent formations had occurred. Because of this pitting corrosion, adjustment of the $\mathrm{pH}$ to 11.0 in the $K$ Area pumps does not appear to be a satisfactory method of corrosion control even though total current flows and weight losses were low。

Potential-Current Measurements

The apparatus (Figure 1) for the above current-time tests was used to obtain additional data for constructing potential-current diagrams. Currents flowing across the $1-\mathrm{ohm}$ resistor connected between various combinations of brass, cast iron, and graphite were plotted versus potentials of the individual and connected electrodes according to the method of Evans。(1) The results are the potential-current diagrams shown in Figures 3-9。

The potential-current diagrams for the brass and cast iron samples exposed to the pH 6,6 and $\mathrm{pH} 11.0$ waters, with and without sulfite, described in the preceding section are shown in Figure 3 . Figure $3 a$ shows the data obtained in fresh solutions and Figure $3 b$ shows the data after one week of testing. Curve 1 in Figure 3 a shows the potentialcurrent diagram for the brass-cast iron couple in a fresh solution of the pH 6.6 control water. The curve is symmetrical, indicating that both the cathodic and anodic half reactions are proceeding equally and the corrosion process is under mixed control. Addition of catalyzed sodium sulfite markedly polarized the cathodic half cell reaction occurring on the brass as shown on curve 2. This polarization of 
the cathode indicates that the corrosion is under cathodic control. Possible cathodic reactions are the reduction of dissolved oxygen, $\mathrm{O}_{2}+2 \mathrm{H}_{2} \mathrm{O}+4 \mathrm{e}^{-} \rightarrow 4 \mathrm{OH}^{\infty}$, or the reduction of hydrogen ions, $2 \mathrm{H}^{+}+2 \mathrm{e}^{-} \rightarrow \mathrm{H}_{2}$ 。 Since the catalyzed sodium sulfite removes oxygen from the water, the cathodic polarization is most likely caused by decreasing the corrosion current available from the oxygen reduction reaction.

Increasing the $\mathrm{pH}$ of the water to 11.0 had the effect of changing the brass potential to a more anodic value as shown in Curve 3 of Figure $3 a$. The total galvanic current was thus reduced because the cathodic curve intersects the anodic curve at a lower current value and not because of polarization as above. Mixed control was in operation for the system. Addition of sulfite to the $\mathrm{pH} 11.0$ water further reduced the corrosion current. Although Curve 4 of Figure 3 a indicates that mixed control is in operation for this latter condition, additional tests, not shown in Figure 3, indicate that cathodic control is in effect.

The potential-current diagrams shown in Figure 3 were obtained just before the start of the current versus time curve shown in Figure 2. The high current values shown in curves 2 and 4 of Figure $3 a$ are due to incomplete oxygen removal. llad these curves been obtained one day later when little corrosion current was flowing, after the additional sulfite had been added, the two curves would have been flat, horizontal lines. However, it then would have been impossible to illustrate the cathodic control concept described above.

The potential-current diagrams at the conclusion of the test shown in Figure 2 are given in Figure $3 \mathrm{~b}$. The brass and cast iron potentials had shifted to more anodic values, and the current had increased in the solutions which initially contained sulfite due to the presence of dissolved oxygen.

Additional tests were initiated to determine the effect of graphite on the brass-cast iron potential-current curves since the cast iron pumps have a substantial coating of graphite on their surfaces. These tests were limited to pH 6.6 water since pitting had been found in pH 11.0 water. The diagram for the brass-cast iron curve obtained in 
pH 6.6 water with air bubbling through the water to maintain a constant oxygen supply is shown in Figure 4. This diagram is similar to Curve 1 in Figure $3 \mathrm{a}$. When the brass was replaced by even more cathodic graphite, the cast iron corrosion was increased as shown by the extension of the anodic curve. When the brass and graphite were connected to form a larger cathode (as indicated by $B G$ in the figure) and then connected to the cast iron, the cast iron corrosion was increased still further. Other combinations (brass cast iron to graphite, graphite-cast iron to brass) gave intermediate corrosion currents. The actual condition existing in the pumps could be any of the conditions shown in Figure 4 depending on the relative resistances to electrical currents from material to material, surface ratios, etc. For example, the initial corrosion process would probably be a galvanic coupling between the brass and cast iron. As the cast iron corroded and the surface became coated with graphite, the corrosion would probably be accelerated due to the increased cathodic area. The graphite could form a porous layer and continued cast iron corrosion would occur, or it could form an impermeable coating and stifle the cast iron corrosion. In the latter case, the resultant coupling then would be between the graphite and

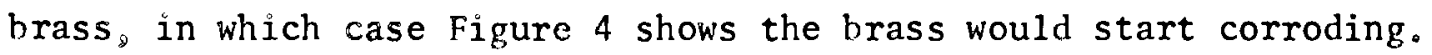
Efforts were made to simulate this situation by corroding a cast iron sample until a graphite layer formed and then coupling the same to brass. The attempt was unsuccessful because the graphite layer was nonadherent and the resulting sample behavior was similar to a normal cast iron sample.

Figure 5 shows the effect of adding catalyzed sodium sulfite to the pH 6.6 water. As before, the corrosion currents between brass and cast iron were almost completely stopped due to cathodic polarization. However, large currents still flowed for cast iron to graphite, brass-graphite to cast iron, and brass-cast iron to graphite couples. Very low currents flowed for the brass to graphite and cast irongraphite to brass couples.

The potential current diagrams shown in Figure 6 were obtained at conditions similar to those shown in Figure 5 except nitrogen was bubbled through the solution as a safety precaution to keep oxygen at low levels. The curves are very similar to those shown in Figure 5 . 
They were obtained after 5 days immersion in the water so that the half cells had become well equilibrated to the environment. Note that several (but not all) of the curves overlap. For example, the graphite cathodic curve of the graphite to cast iron couple is an extension of the graphite cathodic curve for the graphite to brass-cast iron couple.

When only nitrogen sparging was used to deoxygenate pll 6.6 water the currents for all the couples were significantly reduced, as shown in Figure 7. In comparison, as described above, some of the currents obtained when nitrogen was bubbled through sulfite containing pH 6.6 water were not recluced (Figure 6)。 Why this was true is not readily apparent but it was not reproducible in subsequent tests. One possible explanation is that the high currents were due to oxygen previously absorbed on the porous graphite surfaces. In the subsequent tests the graphite to cast iron couple, the couple which did not always exhibit reduced currents, was exposed to pll 6.6 water with nitrogen or air sparging and to pl! 6.6 water containing sulfite additions with and without nitrogen sparging. The results of these tests, shown in Figure 8 , indicate that the corrosion currents were similarly reduced by all three methods of deoxygenating the pH 6.6 water.

The effects of adding $30 \mathrm{ppm}$ of a commercial zinc-phosphatechromate dianodic inhibitor to $\mathrm{pH} 6.6$ water on the potential-current diagrams are shown in Figure 9 . The corrosion currents were slightly reduced from those obtained in untreated $\mathrm{pH} 6.6$ water. The corrosion process was under mixed control. When the dianodic inhibitor concentration was increased to $500 \mathrm{ppm}$ the currents were reduced to low values as shown in Figure 10. The corrosion was reduced due to mixed control (both anodic and cathodic half reactions inhibited, hence the name "dianodic inhibitor")。Total current reductions were not quite as much as with sulfite treatment, however。

The $500 \mathrm{ppm}$ solution was diluted to $30 \mathrm{ppm}$ and the potentialcurrent diagrams for the brass to cast iron couple were constructed. Current flow was the same as that obtained in the $500 \mathrm{ppm}$ solution, indicating that for effective corrosion control a solution of at least $500 \mathrm{ppm}$ dianodic inhibitor must be initially used to condition the metal surfaces before the more dilute recommended concentrations are effective. 


\section{Polarization Measurements}

Cathodic polarization curves for brass and graphite were obtained in pll 6.6 water with and without nitrogen sparging and/or sulfite additions to determine if oxygen reduction was the cathodic reaction occurring on the galvanic couples. The cathodic polarization curve for brass in pH 6.6 filtered Columbia River water with air sparging through the solution is compared in Figure 11 with the cathodic polarization curve for brass in filtered water to which cobaltous chloride catalyzed sodium sulfite and nitrogen sparging were employed to remove the oxygen. The curves were semi-potentiokinetic in that the potential values were changed every thirty seconds rather than letting the current come to equilibrium. Removal of the oxygen was found to polarize the brass cathodic curve in the more negative (active) direction, $i_{0} e_{\circ}$, closer to the potential of the cast iron. This is in agreement with the galvanic measurements in the preceding section. Below about $=800 \mathrm{mV}$, several slopes were obtained indicating more than one cathodic reaction was occurring. In addition, concentration and ohmic polarization effects are possible and could have masked the true slopes so that a definite Tafel relationship was not obtained. Above about $=800 \mathrm{mV}$ in the deoxygenated solution a definite increase in the corrosion current occurred due to hydrogen ion reduction. At above $-1200 \mathrm{mV}$ the reaction became limited by hydrogen ions being unable to diffuse to the cathode fast enough and the current tapered off. Visible hydrogen evolution could be seen in both solutions at about $-1200 \mathrm{mV}$ 。

Since hydrogen ion reduction to hydrogen gas at a rate sufficient to cause significant corrosion was shown to occur above $-800 \mathrm{mV}$ in these solutions and the brass potentials in the galvanic couples were found to be less than $-800 \mathrm{mV}$, hydrogen reduction is not the primary cathodic reaction occurring. The other most common cathodic reaction is the reduction of dissolved oxygen gas to hydroxyl ions. This is probably the predominant cathodic reaction since removal of the oxygen was shown to significantly polarize the cathodic reaction. However, there are probably other species present which affect the cathodic reaction in a lesser amount. 
Cathodic polarization curves for graphite in filtered water with and without oxygen obtained by similar methods as used above are shown in Figure 12. The effect of oxygen removal was shown to also polarize the graphite in the more negative direction. Again, hydrogen ion reduction does not play a significant part in the cathodic reactions at the potentials the graphite normally assumes in the galvanic couples, therefore, oxygen reduction is the most likely reaction occurring on the graphite.

Cathodic polarization curves for freshly etched Zircaloy-2 were obtained as a check on the above polarization curves and also because the cathodic reaction on this material is of interest for other applications. Nitrogen sparging only was used to deoxygenate the filtered water. Several differences were noted in Zircaloy-2 cathodic curves as compared to the brass cathodic curves.

The currents quickly became constant when the potential was changed for the zircaloy 2 samples whereas it would drift for several minutes on the brass samples. When for the few cases the current had not reached a steady value after 30 seconds for the Zircaloy-2, the potential was held at this value until the current did become steady.

Deoxygenation did not markedly change the rest potential of the Zircaloy -2 like it did the brass but the reduction in current at a given potential more negative than the rest potential was more pronounced. These Zircaloy 2 cathodic curves more clearly show the effect of oxygen removal on reducing cathodic currents than do the brass curves. Cathodic currents on Zircaloy -2 in both oxygenated and deoxygenated solutions were much lower than on brass in comparable solutions.

Significant hydrogen ion reduction did not occur on the Zircaloy-2 until the potential was increased to over $-1200 \mathrm{mV}$. This occurred at considerably lower current values than it did on the brass curves shown in Figure 11.

The constant currents obtained within just a few seconds on the Zircaloy -2 and the large difference in the shape of the Zircaloy-2 cathodic polarization curves compared to brass prompted additional determinations on brass where the current was allowed to come to equilibrium. In some cases it was necessary to wait several hours 
before the current stopped drifting after a potential change. The resulting cathodic polarization curves are shown in Figure 14 along with the curves from Figure 11 for reference. The polarization curves in oxygenated water obtained by allowing the current to come to a steady value were similar to those obtained previously (reference Curve 1 in Figure 14), therefore, are not shown in Figure 14. The polarization curve (Curve 3 ) obtained in deoxygenated water (obtained by nitrogen sparging) using steady-state current values exhibited much lower current values at a given potential than did the reference curve (Curve 2). The curve was very erratic and did not exhibit any extensive linear (Tafel) regions. Part of this could be because even with the long waiting periods the current was probably not the equilibrium current for most points on the curve, as exemplified by the lower current value for the point where the sample was left overnight at $-700 \mathrm{mV}$. Part of the erratic behavior could also be due to the presence of other reduction reactions competing with the reduction of dissolved oxygen.

The effects of competing reduction reactions were checked out by holding a sample for a few hours at $-1400 \mathrm{mV}$ to remove any reducible contaminants and then obtaining a polarization curve. The result is Curve 4 in Figure 14. This is probably the best curve obtained in respect to showing the oxygen reduction reaction on brass (a small amount of oxygen remains even when nitrogen is sparged). The free potential of the sample was about $-580 \mathrm{mV}$. When a cathodic potential was impressed the resulting polarization curve did not exhibit the erratic behavior shown in Curve 3 . The curve exhibited typical oxygen concentration polarization in the region of -600 to $-800 \mathrm{mV}$ as shown by the decreasing slope. When Curve 4 is compared to Curve 1 it is seen that the effect of reducing oxygen concentration is to greatly reduce the cathodic current.

At the completion of the run in determining Curve 4 of Figure 14 the nitrogen sparging was quickly stopped and air sparging initiated without changing the sample or the solution. The rest potential came back to about $=200 \mathrm{mV}$ similar to that found in Curve 3 rather than the $\infty 600 \mathrm{mV}$ found in Curve 4 . It is suspected that the difference is due to either a film of oxygen absorbed on the brass surface or, more 
likely, due to an actual oxide formed on the surface. The reduction of the oxide film in addition to the reduction of oxygen would account for some of the erratic behavior shown in Curve 3 .

\section{DISCUSSION}

The effectiveness of deoxygenation of the $\mathrm{pH} 6.6$ filtered Columbia River water with catalyzed sodium sulfite, nitrogen sparging, or a combination of the two in reducing the galvanic corrosion currents between brass and cast iron was clearly demonstrated in the preceding sections. However, these methods of deoxygenating the water did not consistently reduce the galvanic corrosion currents between graphite and cast iron couples. The reason for this is not clear, but the polarization curves indicated that the cathodic half-cell reaction is quite complicated and probably involves several cathodic reactions. One approach to obviate this problem would be to sand blast the graphite from the cast iron $K$ Area diesel powered emergency-coolant pumps so that the primary materials remaining are brass and cast iron. It is then possible to inhibit further corrosion in the system with sodium sulfite additions. Sodium sulfite additions are already being considered to control tuberculation in adjacent $K$ Area pipelines; combining the treatment facilities for the pipelines and pumps could possibly be done with few additional expenditures。

\section{REFERENCES}

1. U。 R. Evans, "The Corrosion and Oxidation of Metals", Arnold, London, 1960。 


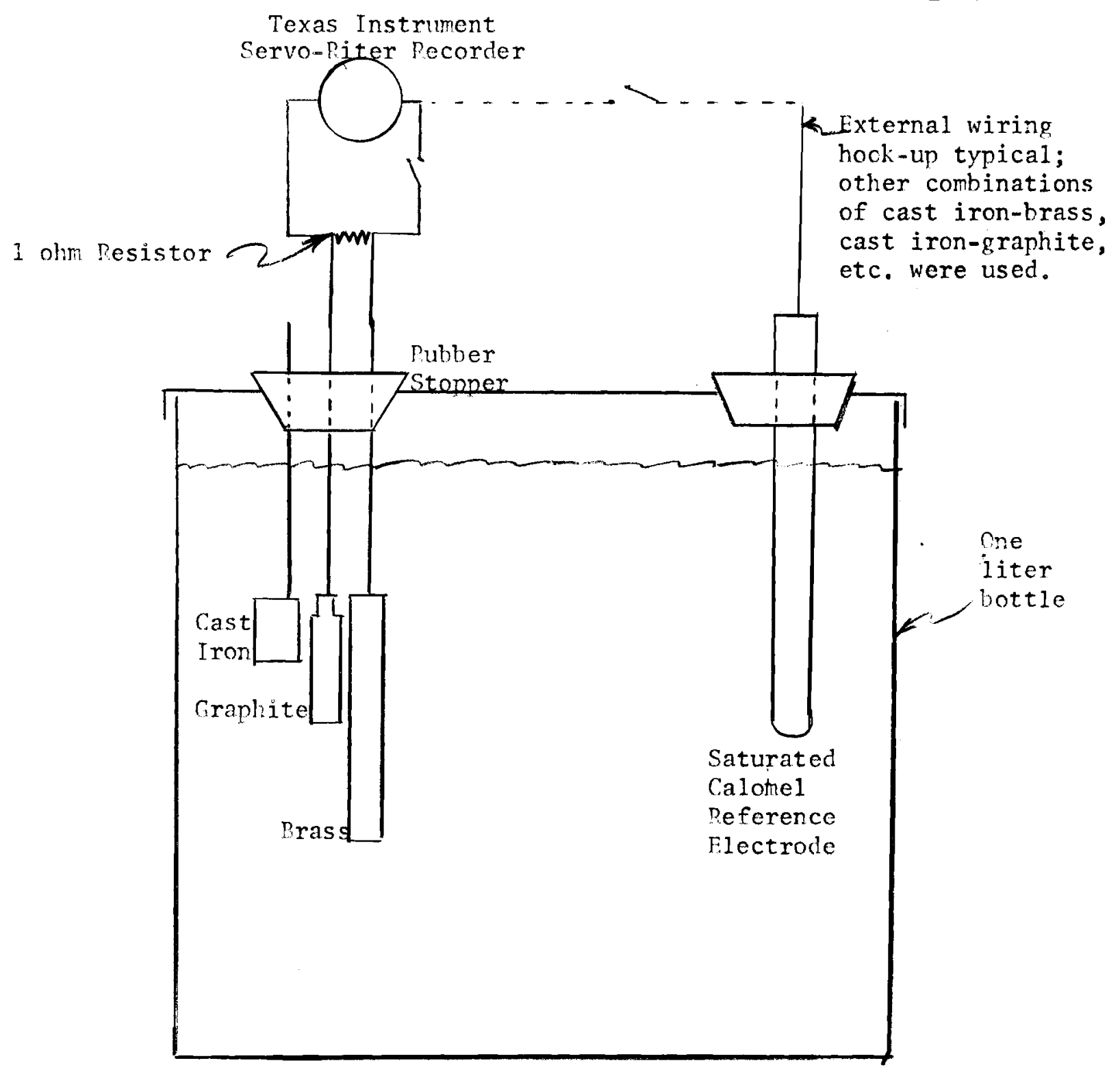

FIGURE 1

LABORATORY APPARATUS FOR POTENTIAL-CURRENT MEASUREMENTS 
FIGUR: 2

Current-Tinac Curves for irass-Cast Iron Counles

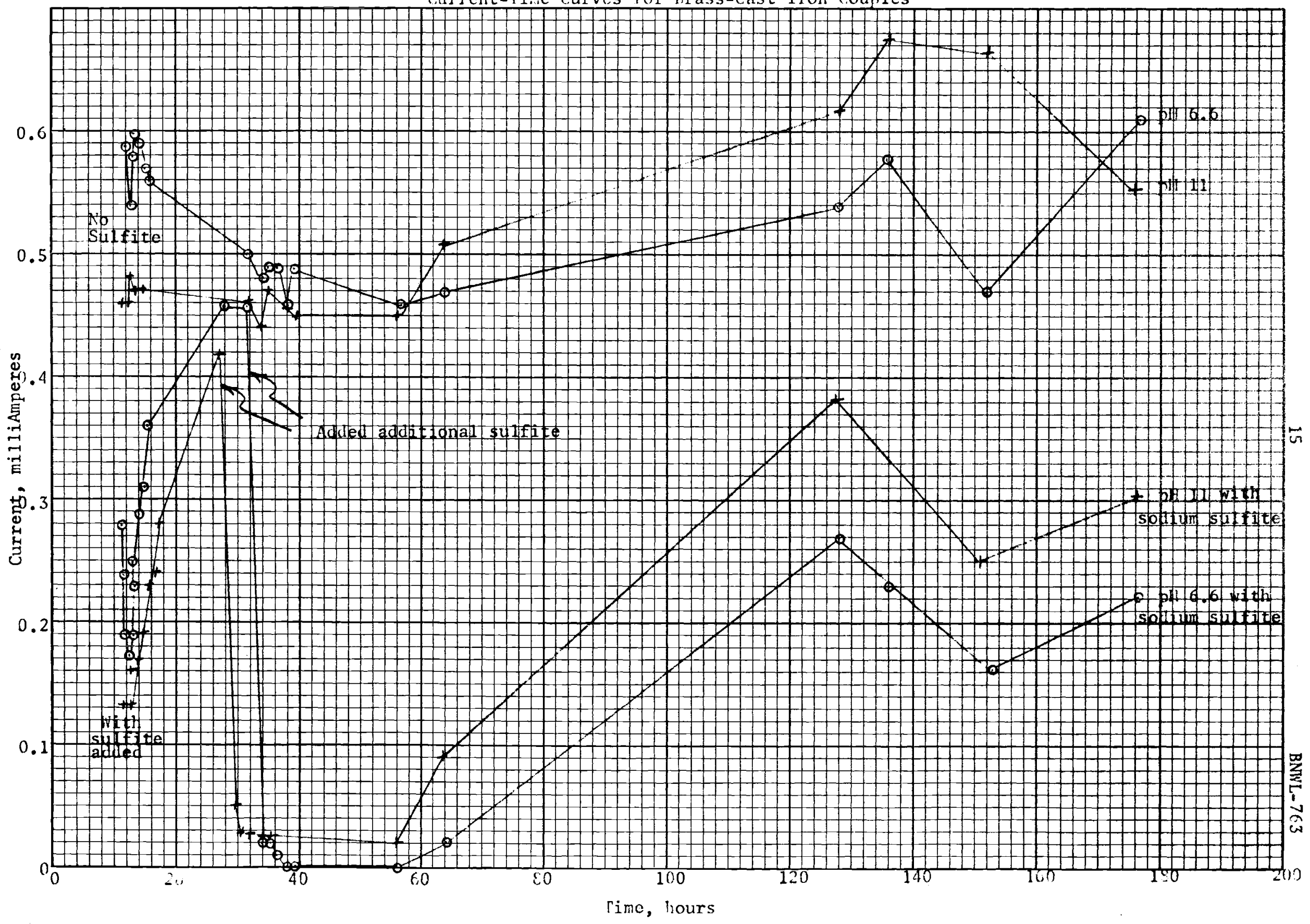


FIGURE 3

Potential-Current Curves for Brass-Cast Iron Couples

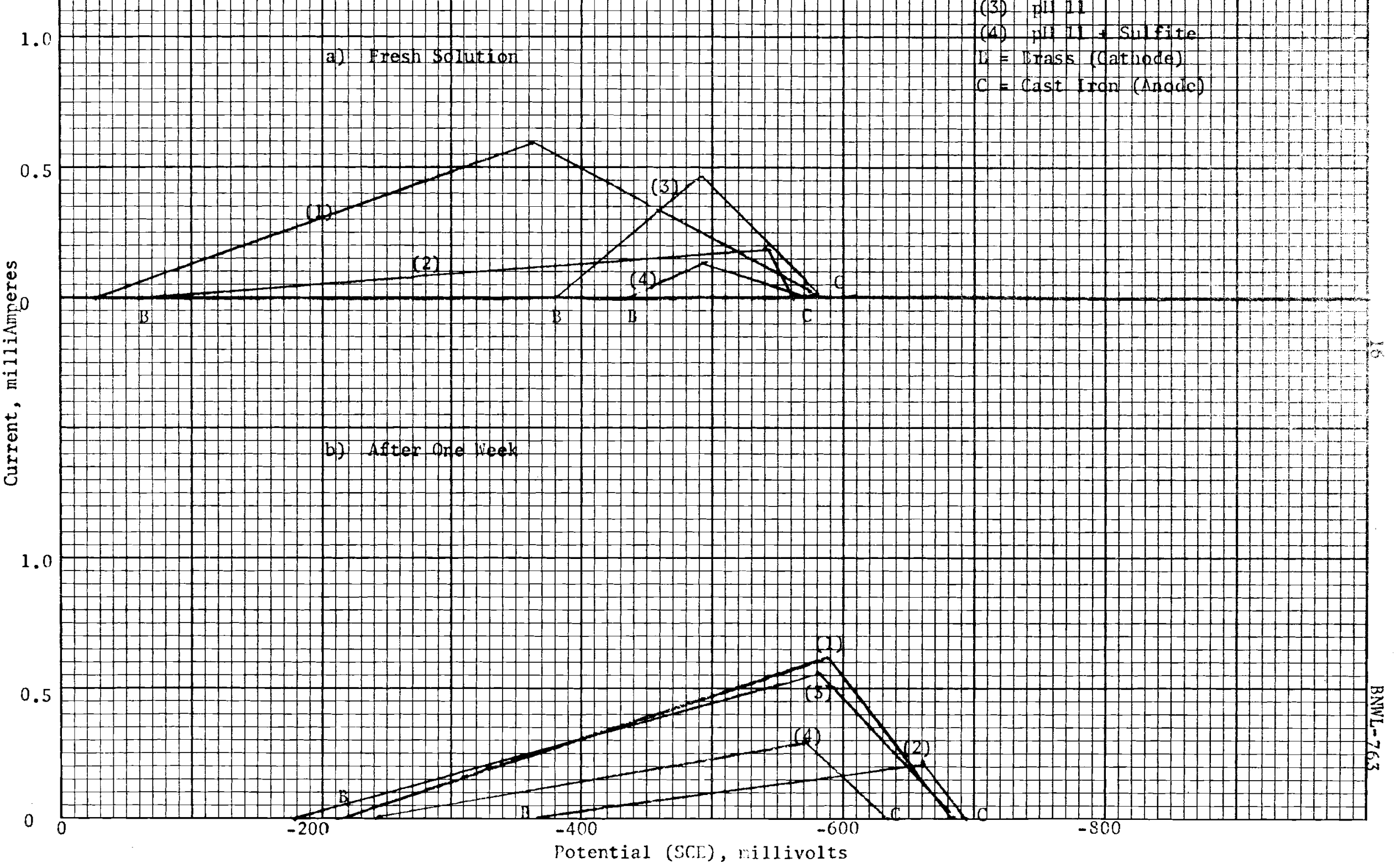


FICURE 4

Potential-Current Curves for Brass-CastIron-Graphite Couples

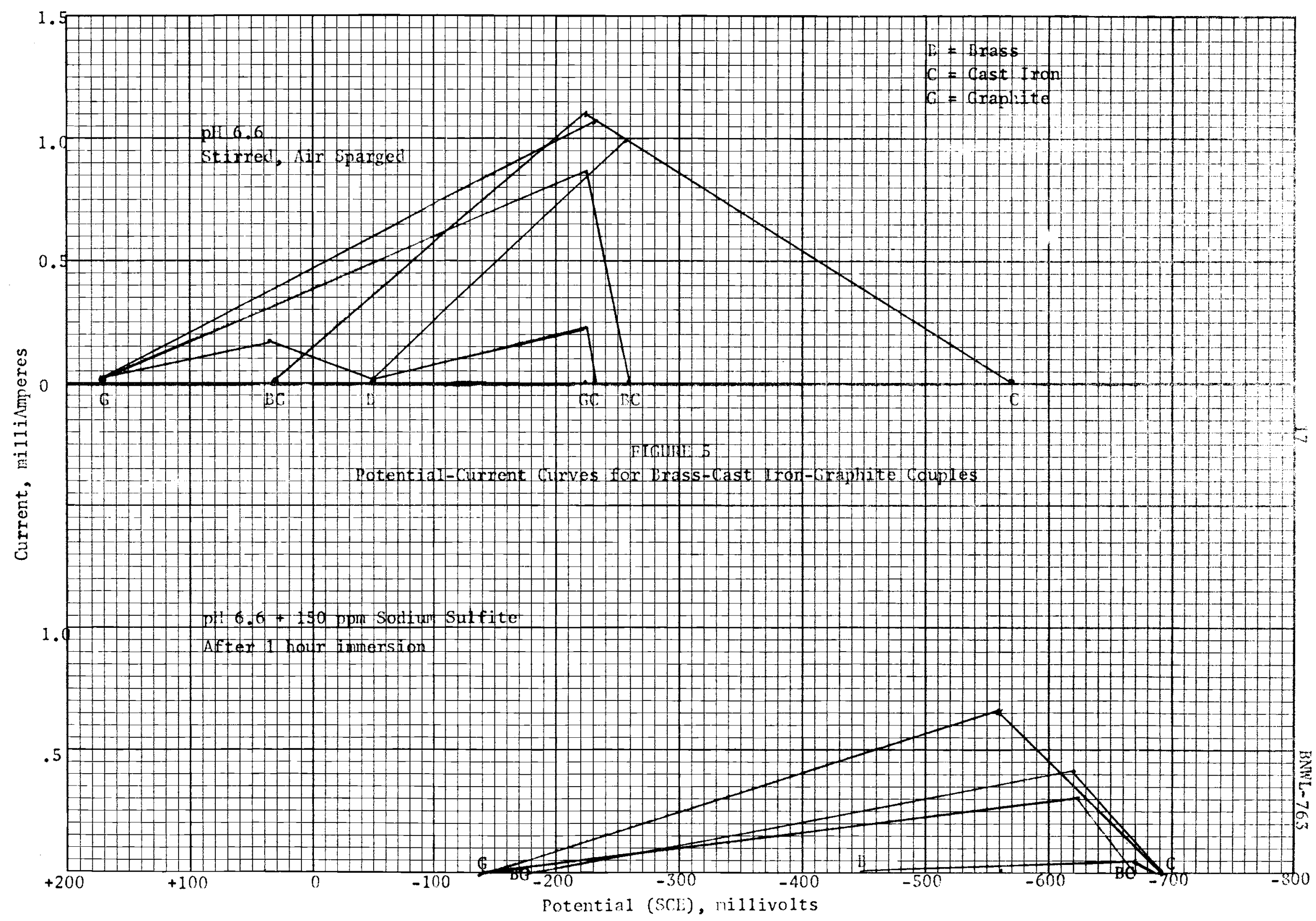




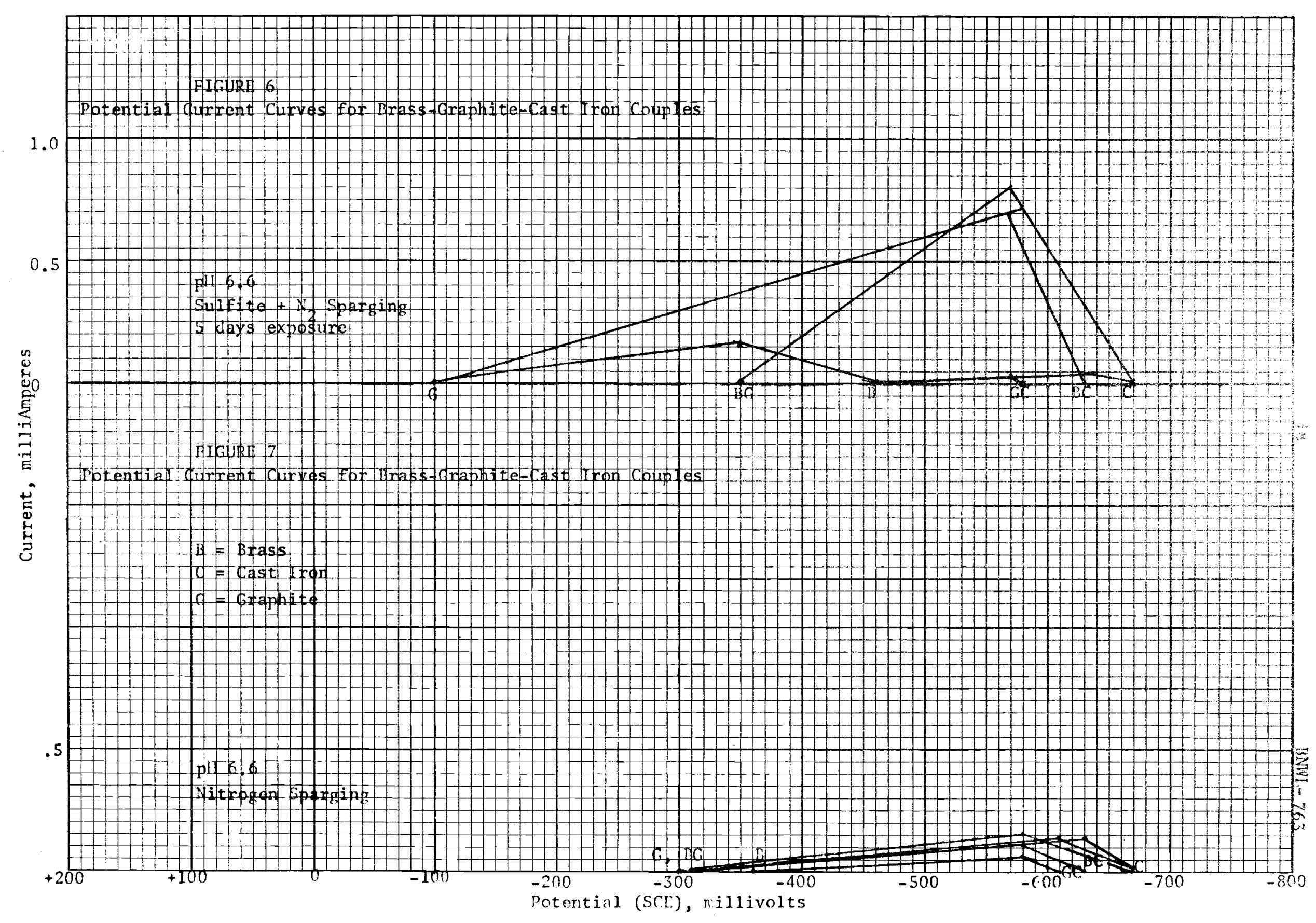


FIGURF 8

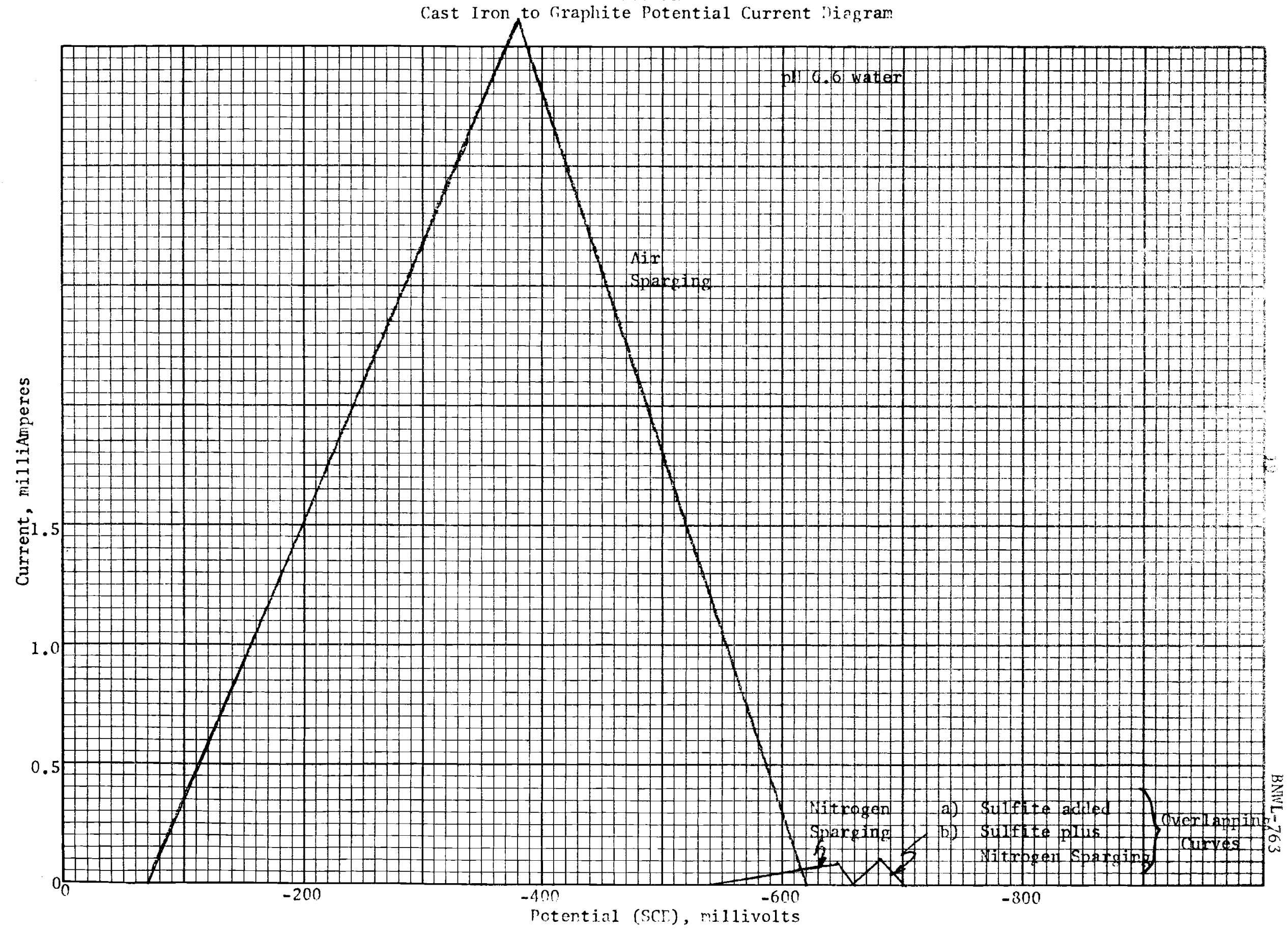


FICUPS 9

Potential Current niagrams in $30 \mathrm{ppm}$ nianodic Inhibitor

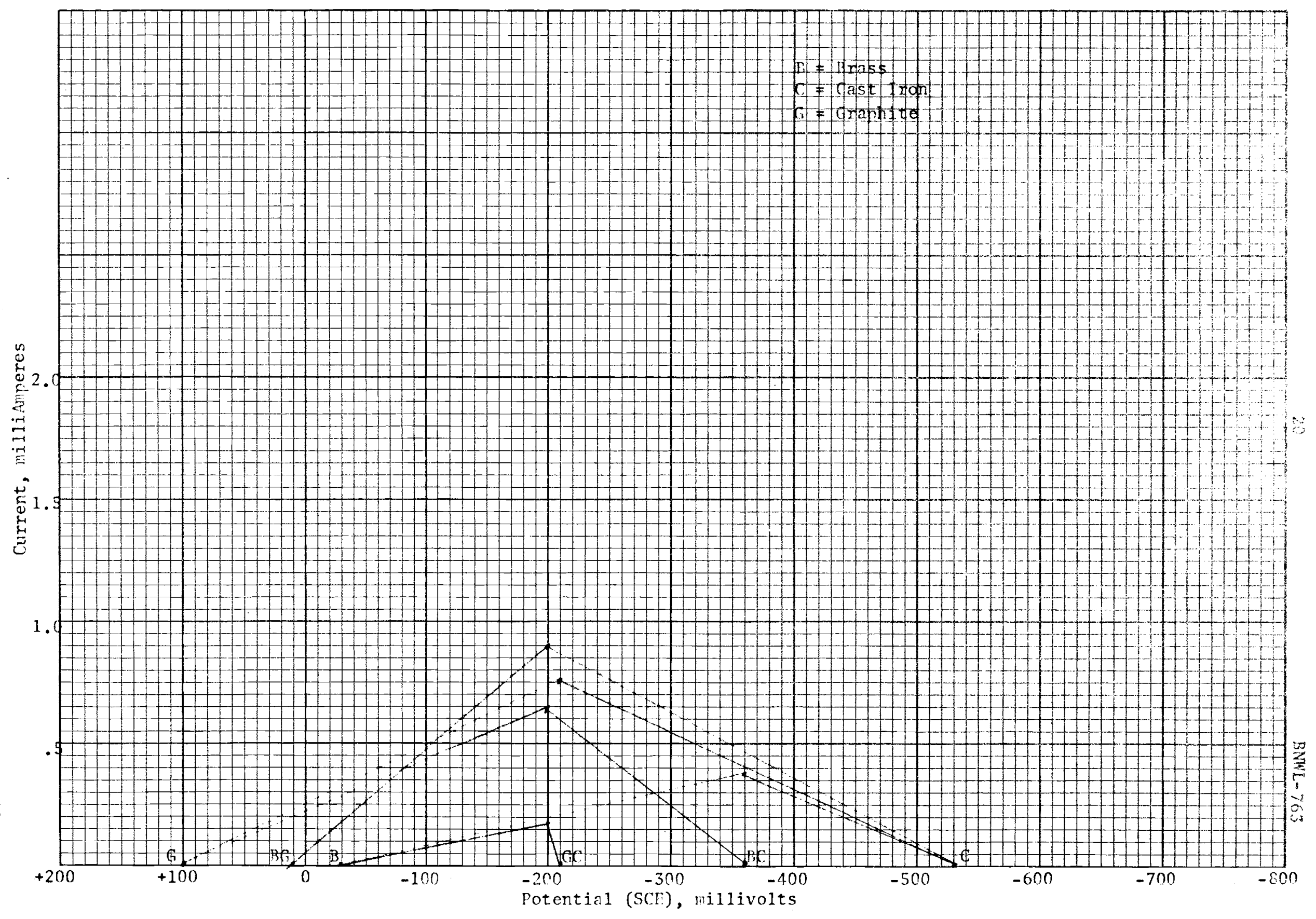


FTCIRF 10

Potential-Current Miagram for Concentrated Iianodic Inhibitor

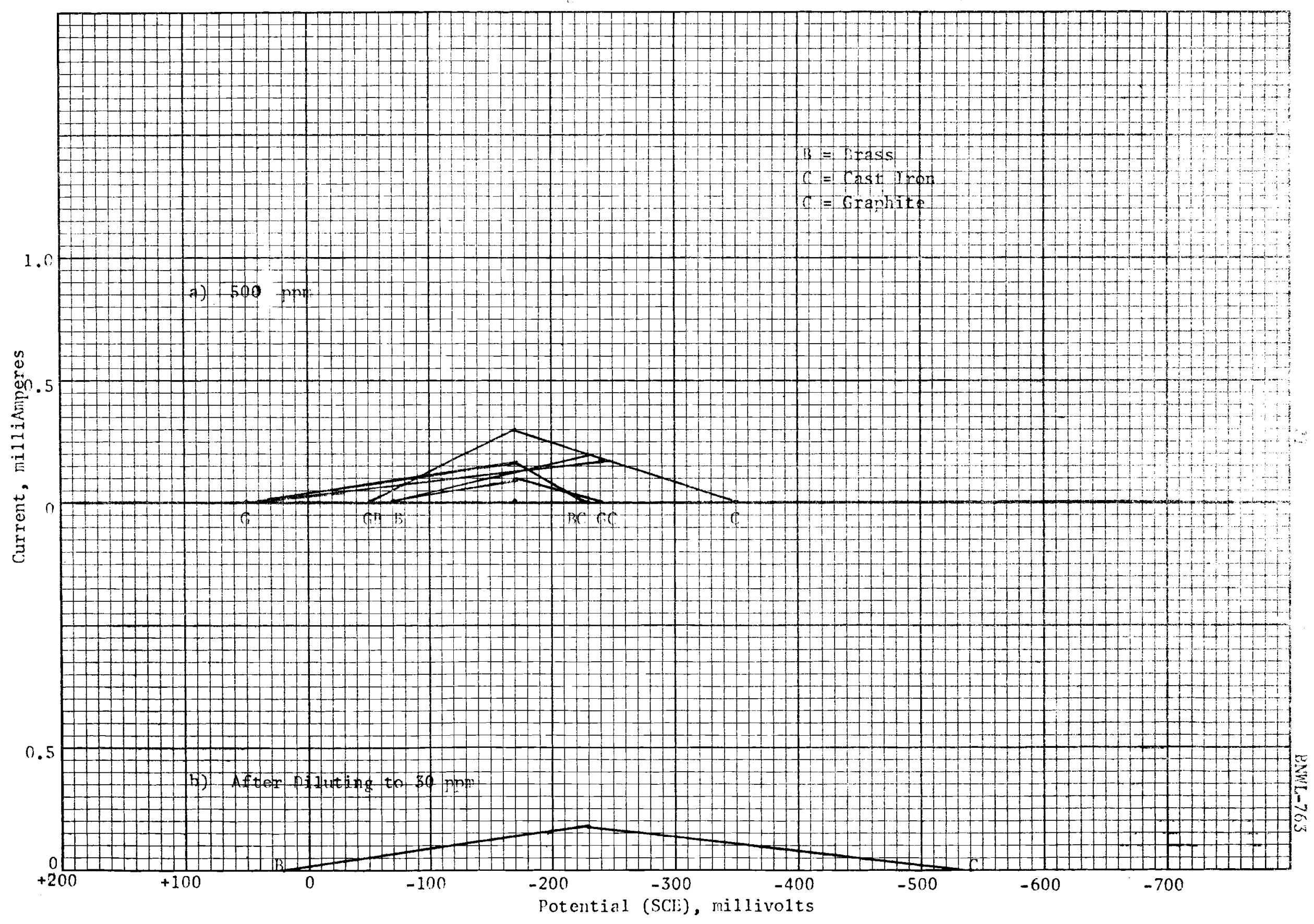




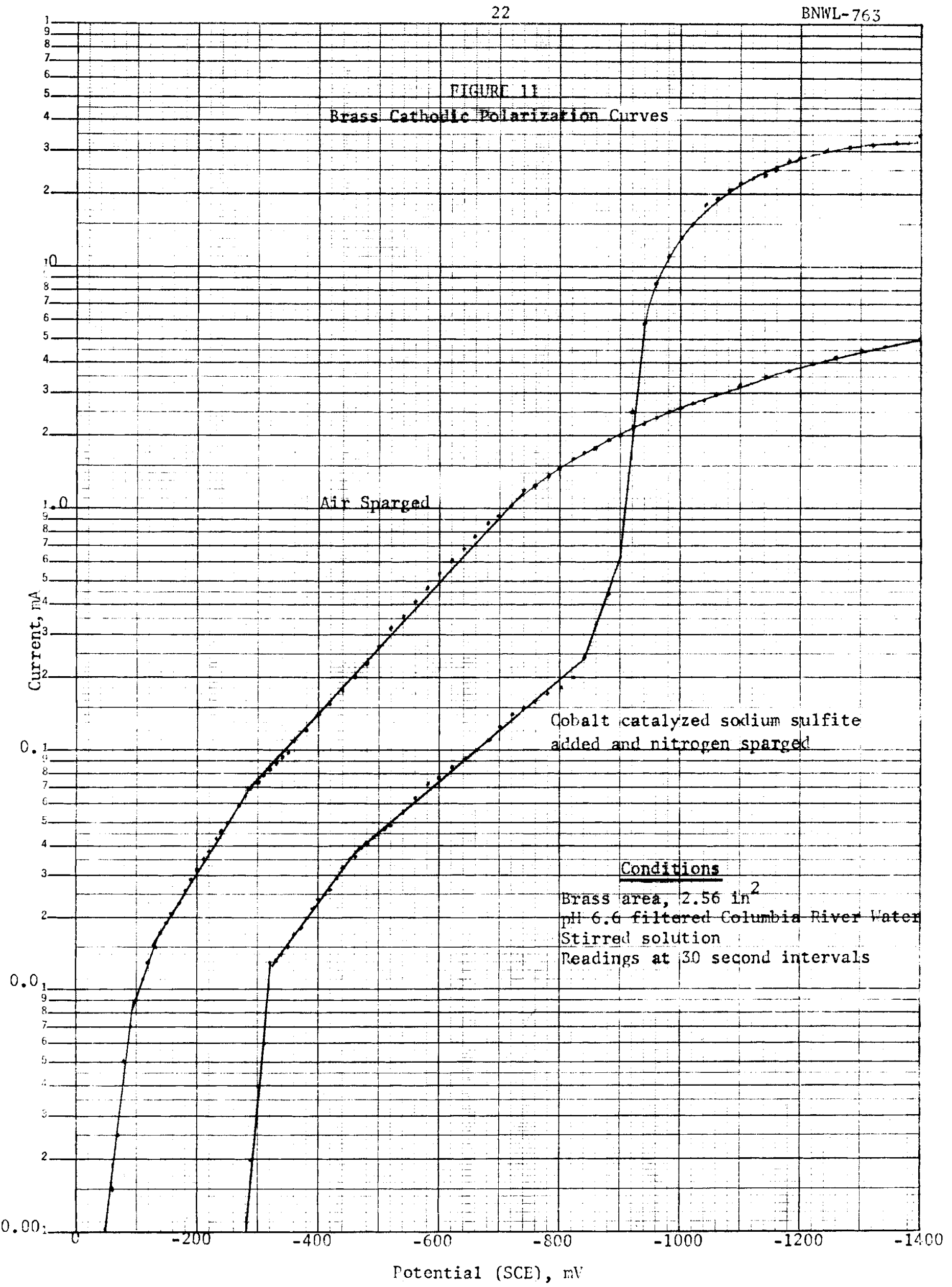




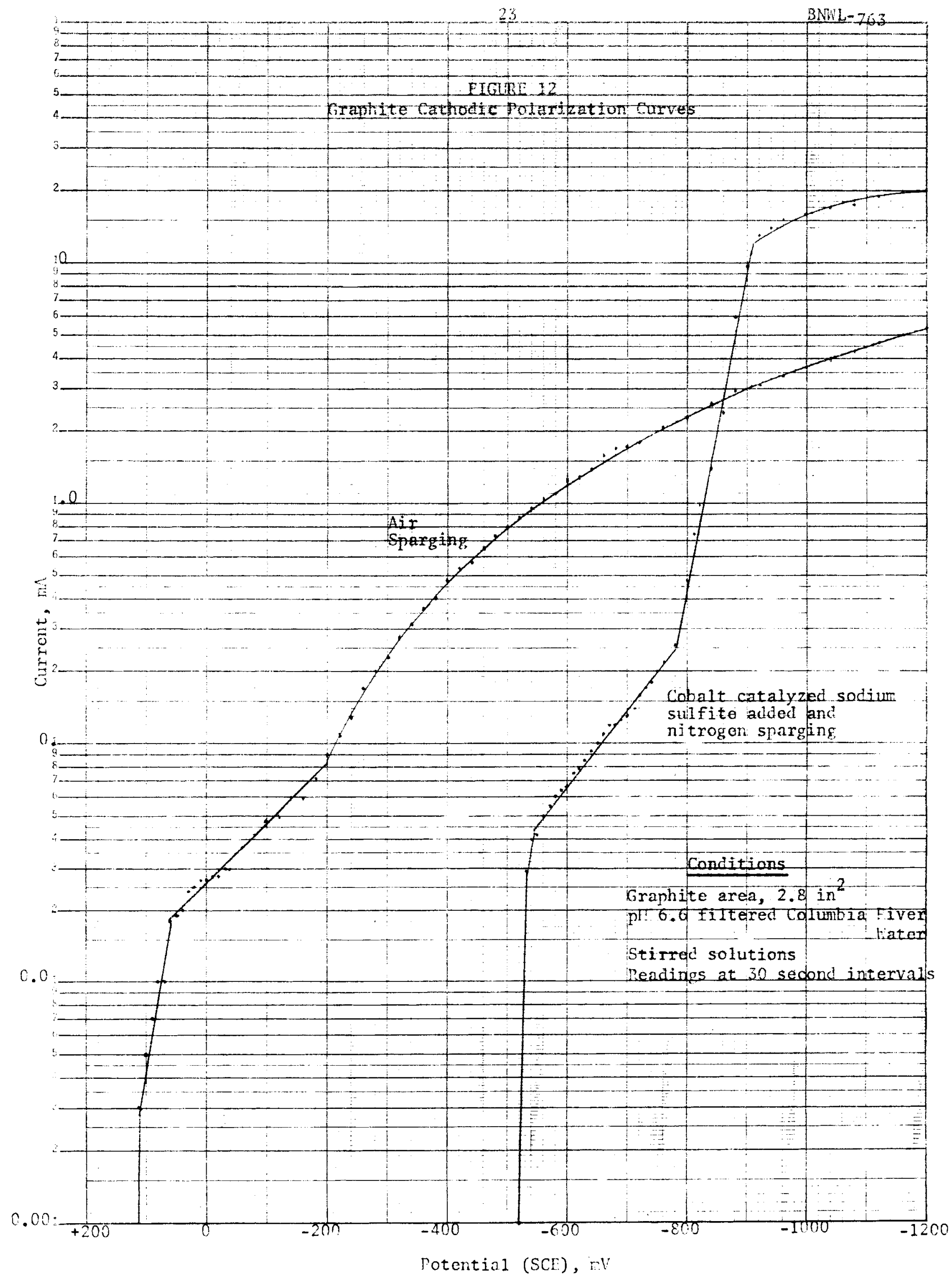




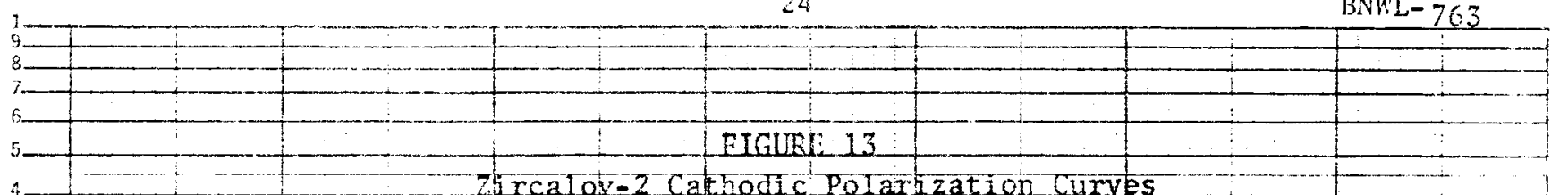

- $p$ ol 6 filfered Collumia kiver Watex

- D No stirring ?

Itciled surface

- 2.9 int $^{2}$ area

- Cilrent allowed to reach steady state before proceeding to next point.

\section{hodic Polarization Curves}
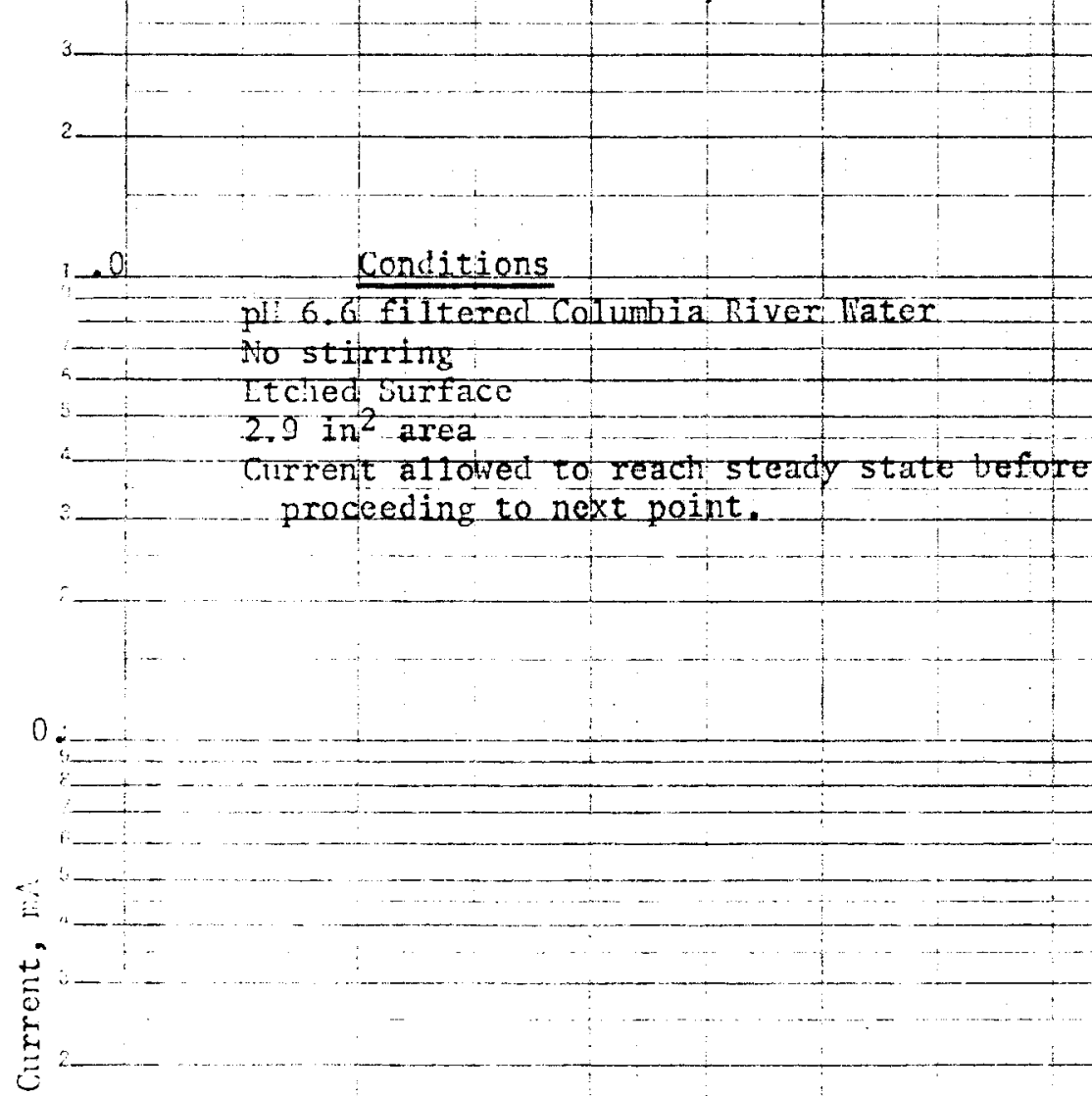

$0.0 \ldots \ldots$ _ Air sparges

-

$\mathrm{O}_{2}+2 \mathrm{H}_{2} \mathrm{O}+4 \mathrm{4}=40 \mathrm{TI}$
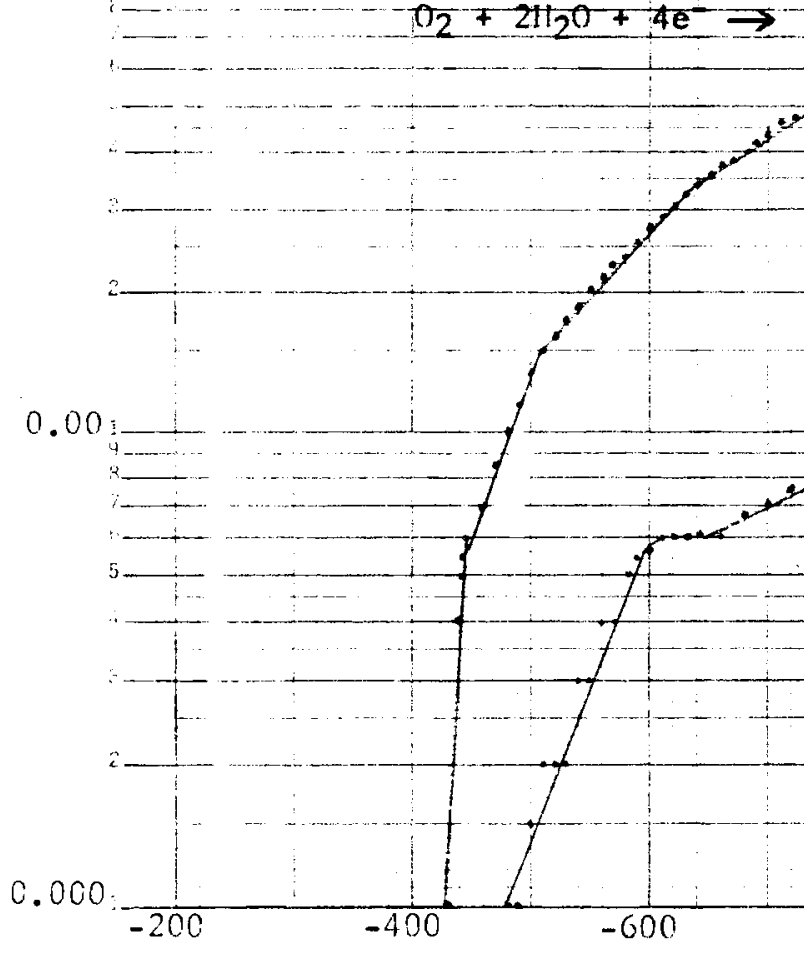

$2 \mathrm{H}^{+}+2 \mathrm{et}^{-} \rightarrow \mathrm{H}_{2}$ 


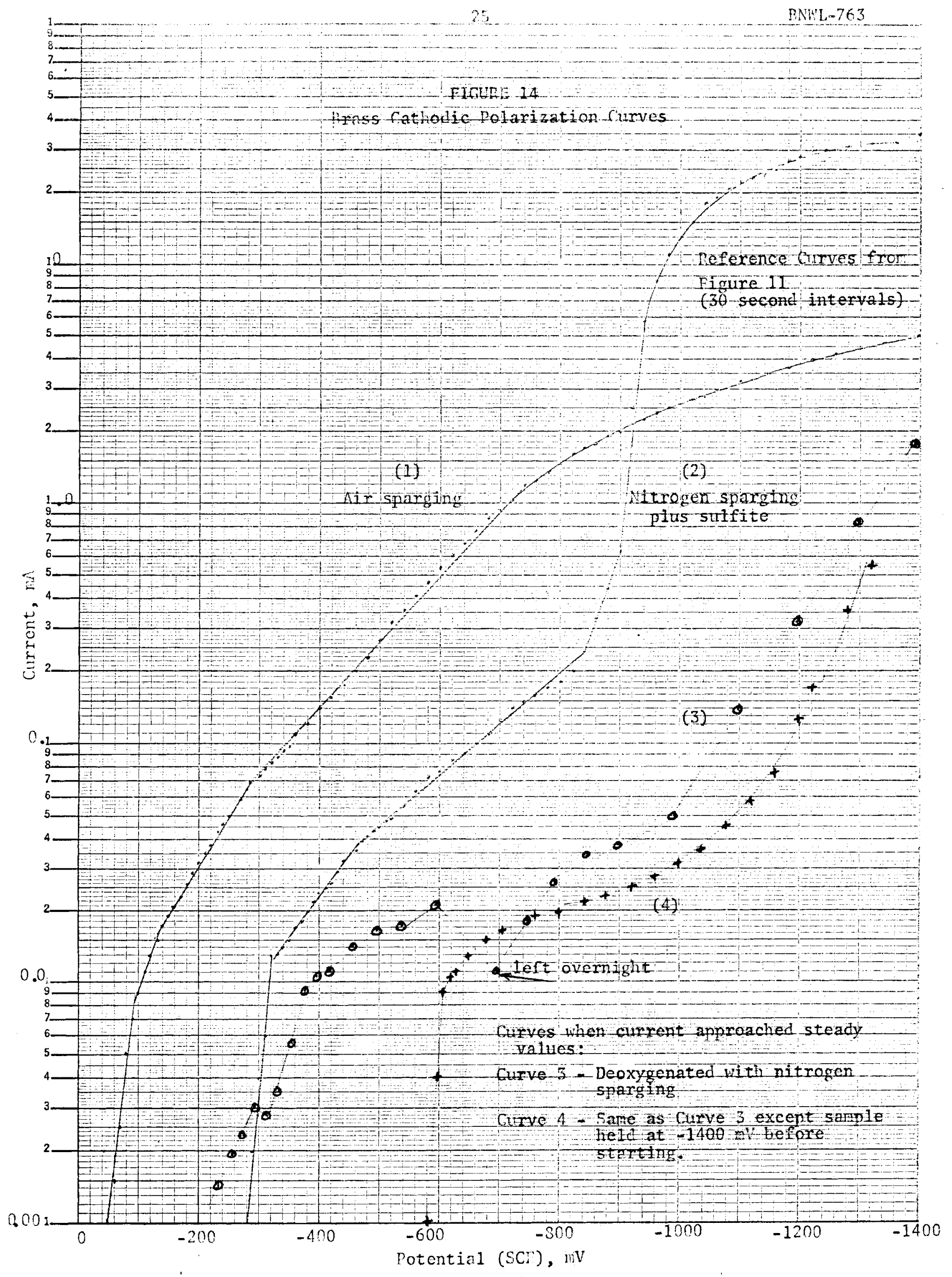


ONSITE MISTR YBUTION

Copy Number

1

2

3

4

$5 \div 9$

10

21

$12-16$

$17 \times 18$

Battel Ie $=$ Northwest

$J \circ \Lambda_{0}$ Ayres

$D$. $R$ 。 de llalas

R. L. Dillon

$B$. Grìgs

A. P. Larrick

R。B. Richman

R. E. Westerman

Technical Information Files (5)

Technical Publications (2)

\section{Douglas-United Nuclear}

19

20

21

22

23

24

25

26

$\cdot 27$

28

29

30

31

32

33

34

35

36

37

38

39

40

$41-43$

$T$. $H$. Ambrose

R. S。Bell

P. A. Carlson

R. G。 Clough

E. L. Etheridge

M. L。 Faught

J。W. Frymier

R。G。Geier

R。 E。 Ilall

$\Lambda$. Ko Hardin

H. W. Heacock

$\mathrm{K}$ 。 L。 Hladek

$M$. Lewis

A. R。 Maguire

J. C. McKay

$\mathrm{J}$ 。C. McLaugh lin

$R_{0} V_{0}$ Myers

R. L。 Olsen

D. W. Peacock

$R, S_{0}$ Peterson

R. W. Reid

A.P. Vinther

Tecinical Information Files (3)

OFFSITE: DISTRIBUTION

Copy Number

44

$\mathrm{AEC}, \mathrm{RL}$

C. L。 Robinson

Technical Library

AEC, RDT Site Representative

P. G。 Holsted 
OFFSITE DISTRIBUTION (Continued)

Copy Number

$47-48$

$49-53$

$54-56$
AEC, Chicago Patent Group

G. H. Lee

R。 K。 Sharp

AEC, DTIE

For UC 80 Distribution (5)

Battelle Memorial Institute (3) 